\title{
DIREITO E LITERATURA: O ABSURDO NO DIREITO EM O ESTRANGEIRO, DE ALBERT CAMUS
}

\author{
LORENA MARTONi DE Freitas'
}

\begin{abstract}
RESUMO: A partir de uma compreensão da filosofia do absurdo desenvolvida por Camus, é possível pensar a obra $O$ estrangeiro sob a ótica jurídica, não apenas em relação aos elementos penais tratados no decorrer do processo de julgamento do protagonista Mersault, mas, inclusive, no que diz respeito às implicações que as noções de "estrangeiro" e de "inimigo" trazem a estudos que abordam identidade e alteridade, bem como a proximidade entre homem e direito, liberdade e moral, apresentados no presente artigo como pilares que sustentam a narrativa de Camus. O trabalho explora, assim, a riqueza emergente de um estudo interdisciplinar que lança mão da Literatura para pensar o Direito, uma vez que compreender os paradoxos exaltados na arte literária permite que tracemos um caminho profícuo para a reflexão crítica sobre a própria natureza do Direito, demonstrando a importante intersecção entre ambas as esferas.
\end{abstract}

Palavras-Chave: direito; absurdo; O estrangeiro; Albert Camus.

\section{INTRODUÇÃO}

Pensar o Direito enquanto um campo do logos, que extravasa os limites positivistas da norma jurídica, é um bom ponto de partida para se compreender as profundezas de suas intersecções com a Literatura. Sendo ambas as esferas resultantes de reflexões humanas sobre a existência - uma ordenadora, outra questionadora -, Direito e Literatura se retroalimentam em um diálogo de espelhos: enquanto o primeiro produz conteúdo formalizado do agir humano sobre o mundo; o segundo, abstraindo esse resultado, devolve ao homem a reação produzida nesse mesmo mundo.

\footnotetext{
${ }^{1}$ Mestranda em Direito (UFMG). E-mail: lory martony@hotmail.com
} 
A Literatura, enquanto campo da arte, atua no rompimento dos vícios de racionalidade que se encontram enraizados em dado recorte temporal, fraturando a realidade em suas infinitas possibilidades. Ao inverter concatenações de fatos e consequências, pressupostos morais e desdobramentos éticos solidificados pelas repetições cotidianas, a arte mostra a fragilidade e o caráter abstrato de um firmamento antes tido como sólido. A partir de um mergulho intenso no subjetivismo que então se revela, novas formatações lógicas são criadas, novas dimensões se formam nas dobras da realidade, e um novo mundo se abre aos olhos de quem escolhe enxergar.

Eis a riqueza proporcionada pela Literatura ao estudo do Direito. No oceano sem fim de possibilidades que a criatividade consegue expressar por meio da linguagem escrita, desponta a infinita complexidade do mundo humano, a ser eternamente ordenado e reordenado pelo Direito, trazendo à tona os paradoxos da existência que criam, concomitantemente, novos problemas e novos caminhos para solucioná-los.

A obra $O$ estrangeiro, de Albert Camus, inscreve-se com maestria nesse jogo imagético entre Direito e Literatura, proporcionando, a cada leitura, novas reflexões sobre a tensão entre sociedade e indivíduo, bem como a sua ilusória dissolução por meio de um Direito instrumentalizado. Escrito em um contexto histórico abalado pelos horrores que insurgiram durante a Segunda Guerra Mundial, $O$ estrangeiro é marcado pelo escancaramento imagético que a narrativa produz sobre as incongruências dos valores morais, e o sistema jurídico que se constrói em cima deles.

A partir desse viés analítico, o presente trabalho busca desvelar essa denúncia contida no referido trabalho de Albert Camus, com o intuito de transferi-la para o estudo do Direito, lançando mão dos benefícios críticos que a inteligência imaginativa do artista gera ao penetrar a racionalidade instrumental do dogmatismo jurídico.

\section{O ABSURDO NA OBRA DE CAMUS}

Datado de 1942 e escrito por Albert Camus, vencedor do prêmio Nobel de Literatura em 1957, o livro O estrangeiro se divide em duas partes ao contar a história de Mersault, protagonista que vive na Argélia: a primeira, uma apresentação da personagem e o desenrolar dos fatos que a 
levam a cometer um homicídio; a segunda, como descrição do julgamento decorrente de seu crime.

"Hoje, minha mãe morreu. Ou talvez ontem, não sei bem" (Camus, 1979, p. 155). Com essa enunciação de abertura, de forma limpa e direta, o primeiro capítulo de $O$ estrangeiro inicia-se exibindo drasticamente o caráter de Mersault, marcado pelo desapego e pela indiferença, responsável por ditar o tom de estranhamento que acompanhará o leitor durante toda a narrativa. Na sequência, informado sobre a morte da mãe, o protagonista descreve sua viagem para o asilo no qual ela se encontrava, sem demonstrar grandes emoções e, inclusive, intrigado pela reação de estranhamento assumida por todos, ao perceberem que o filho não expressava nenhum sinal de tristeza, ou mesmo qualquer forma de abatimento, pela morte da mãe. A sobriedade de Mersault mantém-se constante ao longo da narrativa. $\mathrm{Na}$ primeira parte, torna-se visível no posicionamento impassível do protagonista em relação ao romance travado com Maria Cardona, na amizade proposta por Raimundo e no derradeiro homicídio cometido com os cinco tiros deferidos contra um dos árabes que o perseguia; na segunda parte, pela própria maneira que o protagonista encara seu processo e sua sentença, distante e inabalável.

A obra enquadra-se no que seu autor optou por chamar de "estética do absurdo", em consonância com a teoria explanada em seus trabalhos $O$ mito de Sísifo (1942) e O homem revoltado (1951). Trata-se de escritos resultantes de uma combinação entre seus estudos universitários em Literatura e Filosofia, a experiência de engajamento na Resistência Francesa, durante a ocupação da França pelos alemães na Segunda Grande Guerra, e as estreitas relações com o existencialista Jean-Paul Sartre. No entanto, é exatamente a recusa de aproximar sua teoria do absurdo à doutrina existencialista o motivo de afastamento do jovem Camus do então aclamado filósofo francês. Apesar de também rejeitar a existência de Deus e de um racionalismo absoluto, elementos marcantes no pensamento de Sartre, Camus compreendia o existencialismo como uma doutrina totalizante, uma visão de mundo eivada de princípios metafísicos e morais, elementos pontuais de sua crítica n'O mito de Sísifo, o que implicou necessariamente uma divergência entre os dois pensadores. 
Em $O$ mito de Sísifo, Camus lança mão da mitologia grega para elaborar uma metáfora explicativa do que consistiria seu conceito de "homem revoltado" (1996), subjetividade já apresentada anteriormente por meio da figura de Mersault em $O$ estrangeiro. Na alegoria, Sísifo é condenado pelos deuses a rolar uma enorme pedra até o topo de uma montanha. Mas, logo depois de realizada a tarefa, a pedra era levada a rolar montanha abaixo novamente, condenando Sísifo a realizar um trabalho inútil e sem fim por toda a eternidade. A história é contada originalmente como símbolo da perseverança e da paciência, na qual Sísifo representa a verdadeira paixão do homem pela vida que, a despeito de sua situação de condenado, assume a tarefa de viver nas condições que lhe são impostas.

A história de Sísifo é lida por Camus como representativa da aceitação do homem em viver em um mundo irracional que, ao invés de organizado de forma a direcionar os homens para a compreensão sobre um suposto criador, ou sentido da vida, mostra-se como um nada desprovido de significado, do qual o homem, naturalmente racional e ordenador, sente-se excluído e, por isso, se engana constantemente ao afirmar sentidos para uma externalidade essencialmente caótica e aleatória.

Camus define então o absurdo como o confronto entre esses fatos e ideias naturalmente inconciliáveis. Sua essência não se encontra separadamente no homem ou no mundo, mas na existência relacional de ambos, que culmina na opressão resultante do confronto entre o homem dotado de vontade e o mundo involuntário que o circunda. Consequentemente, o absurdo termina com a morte, assim como todos os outros elementos da vida que envolvem a condição humana:

Da mesma forma, e ao longo de todos os dias de uma vida sem brilho, o tempo nos carrega. Mas sempre chega um momento em que é preciso carregá-lo. Vivemos para o futuro: "amanhã", "mais tarde", "quando você tiver uma situação", "com o tempo você vai compreender". Essas inconsequências são admiráveis porque, afinal, se trata de morrer. Mas chega um dia e o homem verifica ou diz que tem trinta anos. Afirma assim sua juventude. Mas, nesse mesmo lance, se situa com relação ao tempo. Ocupa ali seu lugar. Reconhece que está num dado momento de uma curva que confessa ter de percorrer. Ele pertence ao tempo e, nesse horror que o agarra, reconhece nele seu pior inimigo. Amanhã, ele queria tanto amanhã, quando ele próprio deveria ter-se recusado inteiramente a isso. Essa revolta da carne é o absurdo.

$[\ldots]$ 
Esse mundo em si mesmo não é razoável: é tudo o que se pode dizer a respeito. Mas o que é absurdo é o confronto entre esse irracional e esse desejo apaixonado de clareza cujo apelo ressoa no mais profundo do homem. O absurdo depende tanto do homem quanto do mundo. É, no momento, o único laço entre os dois (Camus, 2015, p. $5-8)$.

Camus reconhece e transmite para sua obra quão absurda é a existência humana que, carente de sentido próprio objetivo, só alcança seus fins, perfazendo-se de significados e verdades, por meio de um processo significante subjetivo a ser realizado pelo próprio ser humano. Nessa esteira, o autor percebe então nos signos e significados existenciais as meras escolhas humanas aleatórias, que são constantemente frustradas pelas ironias do destino - que se constrói, inclusive, sistemicamente, a partir de tantas outras escolhas humanas.

Mas, afastando-se de um niilismo que se conforma na estagnação, a questão do homem camusiano torna-se a possibilidade de se dar sentido à existência, em meio a um universo absurdo. Surge então, dessa empreitada, o homem que vive de acordo com a filosofia do absurdo, caracterizado essencialmente pela autoconsciência deste, e que assim se afirma na revolta, ao aceitar viver uma vida reconhecidamente carente de sentido. Tal homem aceita a ausência de esperança e, em consonância com suas verdades criticamente formuladas, rejeita a priori os significados subjetivos impostos por terceiros, criando seu próprio sentido na escolha de se viver:

\begin{abstract}
As leis da natureza podem ser válidas até um certo limite, após o qual elas se voltam contra si mesmas para fazer nascer o absurdo. Ou, ainda, elas podem se legitimar no plano da descrição sem por isso serem verdadeiras no da explicação. Tudo, então, é sacrificado ao irracional e, uma vez escamoteada a exigência de clareza, o absurdo desaparece com um dos termos da comparação. O homem absurdo, ao contrário, não processa esse nivelamento. Reconhece a luta, não despreza de modo algum a razão e admite o irracional. Desse modo, ele encobre do olhar todos os dados da experiência e não está nada disposto a saltar antes de saber. Ele sabe, somente, que nessa consciência atenta não há mais lugar para a esperança (Camus, 2015, p. 15).
\end{abstract}

Esse homem absurdo descrito por Camus se perfaz na narrativa de $O$ estrangeiro sob a figura de Mersault, o homem absolutamente sincero, liberto das forças conformadoras que o circundam. Aquele que transcende os padrões sociais, não apenas por meio de atos afastados da moralidade 
vigente que os qualificam, mas, principalmente, pela própria indiferença assumida frente a julgamentos reconhecidos como carentes de sentidos (por serem essencialmente externos à esfera individual do ser julgado, único capaz de dar sentido aos próprios atos), se perfaz nessa autoafirmação como um homem que, entregue ao absurdo existencial, chega ao limite da vida sem tê-la negado, revelando a intrínseca incoerência entre o indivíduo e a sociedade. Nas palavras de Camus, no prefácio dessa obra, trata-se aqui de um herói que é condenado por não jogar o jogo social.

\section{O ESTRANGEIRO NO DIREITO}

\section{O inimigo}

A partir da noção filosófica do absurdo adotada por Camus, é possível traçar uma análise do comportamento de Mersault em $O$ estrangeiro, frente aos acontecimentos narrados, adotando uma perspectiva jurídica.

Nascido em 1913, na Argélia, durante sua colonização pela França, Camus veio de uma família com poucos recursos, advinda da região da Alsácia e que de lá emigrou em 1870, quando a região passara para o domínio da Prússia. Seu pai morreu na batalha do Marne durante a Primeira Guerra Mundial, e por isso Albert cresceu sob os cuidados da mãe, Catherine Sintès, uma marroquina de origem espanhola. Quase trinta anos depois, Camus ruma para Paris, em 1940, e depois novamente para Argélia, ambas as mudanças resultantes da sua inconformidade com censuras à imprensa no período da Segunda Guerra, bastante focalizadas nos jornais em que trabalhava, o Alger Republicaine e o Paris-Soir. Em 1942, retratando subliminarmente essa atmosfera sem esperança e sombria, publica $O$ estrangeiro, livro no qual a experiência do deslocamento físico vivido pelo próprio autor mostra-se latente na descrição do deslocamento psíquico provocado pela noção do absurdo, servindo como matéria prima para a caracterização da personagem Mersault.

O estrangeirismo metafórico revela-se então em camadas na obra de Camus. O estrangeiro que escreve fala de um cidadão estrangeiro ao processo jurídico que julga suas ações, situação essa que, por sua vez, representa a realidade do indivíduo que é estrangeiro à própria existência. E, não por acaso, a narrativa se perfaz na função de provocar um 
estranhamento no leitor, que se move também no espaço virtual de seu posicionamento em relação ao protagonista, denunciando aí o descomprometimento moral do homem. Pois, se em um primeiro momento, o leitor se reconhece deslocado em relação à subjetividade de Mersault, marcada pela indiferença, descaso e apatia, no decorrer da história, esse mesmo leitor passa a se perceber cúmplice do protagonista, incomodado com a arbitrariedade moral que assume contornos jurídicos durante o julgamento, e, por fim, sentindo-se até mesmo injustiçado pela derradeira condenação de um assassino.

$\mathrm{Na}$ obra $O$ vocabulário das instituições indo-europeias, Émile Benveniste desenvolve um enraizado estudo etimológico, revelando que "as noções de inimigo, de estrangeiro e de hóspede, que para nós constituem três entidades distintas - semânticas e jurídicas - apresentam íntimas conexões nas línguas indo-europeias antigas" (1995, p. 354). Desse ponto, o autor revela a força simbólica que esses termos trazem consigo, relacionando semanticamente os termos hostis (inimigo) e hospes (hóspede) como duas faces do mesmo fenômeno: o estrangeiro.

Primeiramente, Benveniste identifica uma profunda correlação semântica entre a expressão "homem livre" e o termo antônimo do "escravo", uma vez que o primeiro é aquele "nascido dentro" da sociedade considerada e, portanto, dotado da plenitude de seus direitos, e o segundo, inversamente, como quem não é livre, pois é necessariamente alguém que não pertence a essa sociedade, um estrangeiro sem direitos (Benveniste, 1995, p. 354).

Essa ligação entre o estrangeiro e o escravo teria sua origem em antigos costumes, nos quais o escravo era sempre aquele "de fora", constituído como prisioneiro de guerra. Assim, tanto nas sociedades indoeuropeias primitivas quanto nas velhas sociedades não-indo-europeias, o escravo era um homem sem direitos, submetido a essa condição devido às leis da guerra, não existindo, portanto, escravos que fossem cidadãos (Benveniste, 1995, p. 349).

Essa contraposição entre cidadão e estrangeiro, que posiciona $o$ segundo como inimigo político do primeiro, traz consigo a afirmação ontológica de um grupo social que se define inclusive a partir daquilo que não se é. Ou seja, por um processo identitário de associação e dissociação, o 
inimigo político surge como o outro existencial, aquele que "traz a negação da existência do primeiro, devendo portanto ser repelido e combatido, para a preservação da própria forma de vida, segundo sua modalidade de ser" (Schmitt, 1992, p. 52). Jacques Derrida resgata essa questão do estrangeiro, claramente representada nos diálogos platônicos, nos quais a personagem do estrangeiro aparece frequentemente como aquela que questiona o logos tradicional da cidade $^{2}$, ou seja, a racionalidade que sustentava a organização social e definia não apenas o cidadão, mas o próprio homem grego (Derrida, 2003).

É o reconhecimento de um "não pertencimento" das premissas morais que fundamentam a personalidade de Mersault, a razão para um julgamento que o define como um sujeito essencialmente inadequado, e que por isso deve ser extirpado do seio social no qual se encontra. Essa construção do estrangeiro junto à noção de inimigo solidifica-se no Direito Penal desde os tratados da Escola Clássica, fundada na teoria do Contrato Social. Esta, concebida no contexto iluminista, pressupunha a igualdade absoluta entre todos os homens, enquanto entes dotados de uma razão universal capaz de alcançar verdades absolutas. Desenvolveu-se então sob o fundamento da possibilidade de um consenso entre homens racionais acerca da moralidade, concluindo por fim que todo comportamento desviante é essencialmente patológico, irracional e defeituoso. Nesse sentido, o autor da ação é consequentemente considerado ou incapaz de celebrar contratos, e por isso deve ser corrigido/reeducado por meio da sanção, ou um desertor, que rompeu o pacto conscientemente, tornando-se automaticamente um inimigo da sociedade, sendo essa inimizade que o levará a suportar o castigo que lhe for imposto (Bitencourt, 2008, p. 51).

Essa última compreensão foi desenvolvida por Gunther Jacobs na teoria denominada Direito Penal do Inimigo, divulgada em 1985, que defende ser inimigo do Estado aquele que se afasta permanentemente das normas jurídicas e que não oferece nenhuma possibilidade de reabilitação. Uma vez assim qualificado, o indivíduo sofreria a imposição de uma fórmula de execução da pena diferenciada da aplicada aos considerados cidadãos. Esse tipo de racionalidade punitiva remonta a Mezger,

\footnotetext{
${ }^{2}$ Vide os diálogos Sofista e Político, de Platão (1991a; 1991b).
} 
reconhecido colaborador do nazismo, e à prática da "culpabilidade pela condução de vida", na qual se considera como núcleo da culpabilidade não o fato, mas o autor:

O que importa realmente para a censura é a personalidade do agente, ou seu caráter, ou a sua conduta social, em última análise, o que ele é, e não o que faz, não o como faz. Uma concepção dessas, voltada exclusivamente para o autor, e perdendo de vista o fato em si, o seu aspecto objetivo, pode levar, como de fato levou, na Alemanha nazista, a um arbítrio estatal desmedido, a uma intervenção indevida no modo de ser do indivíduo. Nesse sentido, pune-se alguém por ser determinada pessoa, porque apresenta determinadas características de personalidade, e não porque fez algo, em última análise. Essa concepção justificaria, por exemplo, intervenções cada vez mais em desacordo com a proteção de direitos e garantias individuais, podendo chegar, numa fase mais avançada, a um arbítrio sutil, modelando, inclusive, a personalidade do indivíduo (Bitencourt, 2008, p. 345).

Levando em consideração a influência da Segunda Guerra Mundial nas reflexões de Camus, é clara a relação da teoria do inimigo e dos pressupostos universalistas que a sustentam com a crítica retratada no julgamento de Mersault. O protagonista, definido como modelo do homem que assume o absurdo na incongruência entre indivíduo e coletividade, enquadra-se perfeitamente na categoria do inimigo traçado na teoria de Jacobs. Afinal, Mersault não apenas comete um ato típico, ilícito e culpável, mas também não se arrepende e, principalmente, não é afetado pelos valores ou punições sociais com que é ameaçado. O próprio fato de o protagonista não concordar em construir uma defesa com base em afirmativas falsas demonstra seu descaso, traço esse que representa sua autoafirmação na recusa à modelagem externa que tentam lhe infligir.

Logo, se ao estrangeiro e ao inimigo relaciona-se etimologicamente à ideia de escravo, cuja liberdade é tolhida em prol da vontade de outrem, em Camus a revolta surge como autoafirmação necessária do estrangeiro enquanto homem livre, cuja vontade mantém-se firme frente a todos os grilhões que lhe são impostos. Pois, como convém ao homem revoltado, que vive sua vida na constância e na aceitação do absurdo, mais vale ser coerente aos seus princípios e convicções. 


\section{O processo}

O protagonista de Camus apresenta-se então como o próprio homem revoltado, ou seja, aquele que, além de se perceber como não pertencente a uma subjetividade externa à sua individualidade, nega-a ao ponto de seus comportamentos se constituírem em hostilidade e que, mesmo assim, acata o absurdo dessa colisão. Isso fica claro na esteira da segunda parte, quando Mersault é condenado por não ceder às artimanhas jurídicas, mantendo-se fiel à sua verdade, ao seu próprio eu.

A vida de Mersault, sua sequência de escolhas ou eventos aleatórios, sensoriais, passageiros, responsáveis pela constituição de uma esfera espaço-temporal natural na qual se construiu seu caráter subjetivo e individual, consubstancia-se em determinado momento em um resultado pontual, que choca com as predeterminações jurídicas de um meio social externalizado, estranho. Em outras palavras, a existência imposta ao homem, seu destino regido pela estrela maior - o sol atordoante - que figura incessantemente durante toda a narrativa, culmina em um fato que vem a ser significado, a posteriori, como antijurídico - um homicídio:

Pensei que me bastava voltar para trás e tudo ficaria resolvido. Mas atrás de mim, comprimia-se uma imensa praia vibrante de sol. Dei alguns passos para a nascente. O Árabe não se moveu. Apesar disso, estava ainda bastante longe.

Parecia sorrir, talvez por causa das sombras que se lhe projetavam na cara. Esperei. A ardência do sol queimavame as faces e senti o suor amontoar-se-me nas sobrancelhas. Era o mesmo sol do dia em que a minha mãe fora a enterrar e, como então, doía-me a testa, sobretudo a testa e todas as suas veias batiam ao mesmo tempo debaixo da pele. Por causa desta queimadura que já não podia suportar mais, fiz um movimento para frente. Sabia que era estúpido, que não me iria desembaraçar do sol, simplesmente por dar um passo em frente. Mas dei um passo, um só passo em frente. E desta vez, sem se levantar, o Árabe tirou a navalha da algibeira e mostrou-ma ao sol. A luz refletiu-se no aço e era como uma longa lâmina faiscante que me atingisse a testa. No mesmo momento, o suor amontoado nas sobrancelhas correu-me de súbito pelas pálpebras abaixo e cobriu-as com um véu morno e espesso.

Os meus olhos ficaram cegos, por detrás desta cortina de lágrimas e de sal. Sentia apenas as pancadas do sol na testa e, indistintamente, a espada de fogo brotou da navalha, sempre diante de mim. Esta espada a arder corroía-me as pestanas e penetrava-me nos olhos doridos. Foi então que tudo vacilou. O mar enviou-me um sopro espesso e fervente. Pareceu-me que o céu se abria 
em toda a sua extensão, deixando tombar uma chuva de fogo. Todo o meu ser se retesou e crispei a mão que segurava o revólver. O gatilho cedeu, toquei na superfície lisa da coronha e foi aí, com um barulho ao mesmo tempo seco e ensurdecedor, que tudo principiou. Sacudi o suor e o sol. Compreendi que destruíra o equilíbrio do dia, o silêncio excepcional de uma praia onde havia sido feliz. Voltei então a disparar mais quatro vezes contra um corpo inerte onde as balas se enterravam sem se dar por isso. E era como se batesse quatro breves pancadas à porta da desgraça (Camus, 1979, p. 222).

Na condição humana, o absurdo é a lei da existência, e por isso uma postura de discordância, ainda que constituída no seio da própria existência social, tem um preço quando em conflito com a ordem jurídica/moral que rege a sociedade, pressuposta como ordem pautada em princípios humanos atemporais, e que, por conseguinte, inadmite paradoxalmente os desvios que ela mesma gera. Assim, o absurdo se revela inteiramente na segunda parte da obra, quando o julgamento de Mersault se atém muito mais a elementos característicos individuais da personagem do que ao fato do homicídio em si. Ou seja, o sistema que se pretende objetivo, à parte das contingências existenciais, e que em virtude disso mesmo inadmite esses tipos de desvios morais rege-se no decorrer da narrativa quase que exclusivamente por aspectos subjetivos excepcionais.

Constituído um advogado para sua defesa, este pergunta se Mersault havia sofrido com a morte da mãe, ao que o protagonista responde que "preferia que ela não tivesse morrido" (Camus, 1979, p. 230). O advogado explica que tal insensibilidade seria um ponto forte que a acusação ressaltaria e, ainda, que no julgamento adentrariam fatores externos ao caso em si, envolvendo toda a vida privada do autor do crime. Direcionado o caso ao juiz de instrução, inicia-se o primeiro interrogatório exatamente no sentido apontado pelo advogado, investigando, inclusive, a ausência de fé do protagonista em Deus. Percebe-se claramente que o julgamento de Mersault é muito mais direcionado para sua vida pessoal do que para o crime e seus fatos objetivos, revelando que o fato atípico não era o crime em si, mas sim a identidade desviante do autor do crime:

Mesmo do lugar dos réus, é sempre interessante ouvir falar de nós mesmos. Durante os arrazoados do procurador e do meu advogado, posso dizer que se falou muito de mim e talvez até mais de mim, que do meu crime. Eram aliás assim tão diferentes, estes discursos? O advogado levantava os braços e pleiteava culpado, mas 
com atenuantes. O procurador estendia as mãos e pleiteava culpado, mas sem atenuantes. No entanto, uma coisa me incomodava vagamente. Apesar das minhas preocupações, apetecia-me por vezes intervir e o meu advogado dizia-me então: "Cale-se, para seu bem é melhor que se cale".

De algum modo, tinham todo o ar de tratar deste caso à margem da minha pessoa. Tudo se passava sem a minha intervenção.

Jogava-se a minha sorte sem que me pedissem a opinião. De tempos a tempos, tinha vontade de interromper toda a gente e de dizer: "Mas quem é afinal o acusado? É importante ser o acusado. E tenho coisas a dizer!" [...]

"Podemos dizer, em sua defesa, que este homem exprimiu algum arrependimento? Nunca, meus senhores. Nem uma só vez no decurso da instrução do processo, pareceu emocionado com o seu crime abominável”. Nesse momento voltou-se para mim e apontou-me com o dedo, continuando a fulminar-me, sem que na realidade eu compreendesse muito bem porquê. Não posso deixar de reconhecer, sem dúvida, que ele tinha razão. Não me arrependia muito do que tinha feito. Mas espantava-me uma atitude tão encarniçada. Gostaria de lhe poder explicar cordialmente, quase com afeição, que nunca me arrependera verdadeiramente de nada. Estava sempre dominado pelo que ia acontecer, por hoje ou por amanhã. Mas evidentemente, no estado a que me haviam levado, não podia falar a ninguém neste tom. Não tinha o direito de me mostrar afetuoso, de ter boa vontade. E tentei continuar a escutar, pois o procurador começou a falar da minha alma.

Dizia que se debruçara sobre ela e que nada encontrara, senhores jurados. Dizia que, em boa verdade, eu não tinha alma e que nada de humano, nem um único dos princípios morais que existem no coração dos homens, me era acessível. "Não poderíamos sem dúvida censurarlhe uma coisa destas, acrescentou. $\mathrm{O}$ que ele não teria possibilidades de adquirir, não podemos queixar-nos de que lhe falte. Mas no que se refere a este caso, a verdade negativa da tolerância deve transformar-se na virtude menos fácil, mas mais elevada, da justiça. Sobretudo quando o vazio de um coração como o que descobrimos neste homem se torna num abismo onde a sociedade pode sucumbir". Foi então que começou a falar outra vez da minha atitude para com a mãe (Camus, 1979, p. 269272).

Mersault discorre ainda nos capítulos seguintes sobre a solidão da prisão, a privação da liberdade e as formas de combater o tédio. No dia do julgamento, o protagonista narra sobre a presença da mídia, o desenrolar do júri e de como ele se sentia excluído do processo que tratava de seu próprio crime. As testemunhas de acusação limitavam-se a relatar o comportamento insensível de Mersault em relação à morte da mãe, já as de 
defesa, amigos do protagonista, depunham sobre sua boa índole e caráter. Apesar do constante estranhamento experimentado pelo leitor frente ao julgamento do protagonista, ressalta-se sua atualidade e sua coerência com $\mathrm{o}$ ordenamento e com a prática jurídica brasileira vigente, na qual o subjetivismo impera descaradamente, a despeito do objetivismo apregoado na teoria jurídica. O fato típico, antijurídico e culpável, artificialmente objetivado nas mais diversas categorias formais, é analisado no decorrer do processo sob o signo da reprovabilidade da ação do indivíduo, que, por sua vez, tem em seu cerne a moralidade pré-definida do grupo que a julga em seu sistema de contrapesos. Essa moral operante, travestida sob a figura física de juízes, promotores, testemunhas, jurados, dentre tantos outros envolvidos, principalmente nos julgamentos midiáticos, mescla-se ao individualismo subjetivo de cada um dos envolvidos, multiplicando exponencialmente a subjetividade do julgamento.

Em paralelos mais superficiais, é possível afirmar que, no decorrer do processo experienciado pelo protagonista, a insistente valoração da sua vida pessoal possui ainda claras correspondências com o art. 59 do Código Penal, no qual se determina que a conduta social e a personalidade do agente devem ser consideradas no momento da fixação da pena3. Como consequência, não são poucos os processos que incluem interrogatórios de testemunhas que atestam sobre a índole do réu, bem como cartas de parentes destinadas aos juízes, ou mesmo os discursos dos advogados dirigidos ao júri, apelando para sentimentalismos externos aos supostos fatos objetivos. Assim, o absurdo se revela mais uma vez no vaivém de contradições de um julgamento que se pretende objetivo, mas se aprofunda em caracteres subjetivos, ao mesmo tempo em que aliena o próprio sujeito que analisa, quando pretende cuidar somente dos fatos.

Eis a crítica direcionada ao processo penal, que não apenas se estende por longos períodos, submetendo o réu ao martírio da espera por um

\footnotetext{
3 “Art. 59 - O juiz, atendendo à culpabilidade, aos antecedentes, à conduta social, à personalidade do agente, aos motivos, às circunstâncias e consequências do crime, bem como ao comportamento da vítima, estabelecerá, conforme seja necessário e suficiente para reprovação e prevenção do crime: I - as penas aplicáveis dentre as cominadas; II - a quantidade de pena aplicável, dentro dos limites previstos; III - o regime inicial de cumprimento da PPL; IV - a substituição da pena privativa da liberdade aplicada, por outra espécie de pena, se cabível.”
} 
desfecho institucional, mas principalmente por excluir o próprio réu, que muitas vezes não compreende seu funcionamento, restando-lhe apenas confiar em seu advogado. Tal situação é representada, de forma bastante clara, no seguinte trecho da obra:

Por exemplo, o discurso do procurador depressa me fatigou. Apenas me impressionaram ou despertaram a atenção alguns fragmentos, gestos ou tiradas inteiras, mas desligadas do conjunto.

O fundo do seu pensamento, se bem o compreendi, é que o meu crime fora premeditado. Pelo menos, tentou demonstrá-lo. Como ele próprio dizia: "Darei a prova do que afirmo, meus senhores, e dá-la-ei duplamente. Sob a crua claridade dos factos em primeiro lugar e em seguida sob a iluminação sombria que me será fornecida pelo perfil psicológico desta alma criminosa”. Resumiu os factos a partir da morte da minha mãe, relembrou a minha insensibilidade, a minha ignorância da idade dela, o meu banho de mar, no dia seguinte, com uma mulher, o cinema, Fernandel e por fim o caso com Maria. Levei tempo a compreender nesse momento, porque dizia "a amante" e para mim, ela chamava-se Maria. Chegou, em seguida, à história de Raimundo. Achei que tinha uma maneira de ver as coisas bastante clara. O que dizia não deixava de ser plausível. Eu escrevera a carta de combinação com Raimundo para atrair a amante deste e a entregar aos maus tratos de um homem "de moralidade duvidosa". Provocara, na praia, os adversários de Raimundo. Este ficara ferido. Eu pedira-lhe o revólver. Voltara atrás para me servir dele, sozinho. Tal como projetara, dera depois cabo do Árabe. Disparara uma vez. Esperara. E, "para ter a certeza de que o trabalho ficara bem feito", disparara mais quatro tiros, calmamente, conscientemente, pela certa. "E aqui está, meus senhores, disse o advogado de acusação. Acabo de traçar o fio dos acontecimentos que levaram este homem a matar com pleno conhecimento de causa. Insisto neste ponto. Pois não se trata de um crime banal, de um ato impensado que poderia ser atenuado por certas circunstâncias. Este homem, meus senhores, é um homem inteligente. Ouviram-no falar, não é verdade? Sabe responder. Conhece o valor das palavras. E não se pode dizer que tenha agido sem dar pelo que estava a fazer".

$\mathrm{Eu}$ ouvia, e percebia que me consideravam inteligente. Mas não compreendia por que motivo as qualidades de um homem vulgar podiam erguer-se esmagadoramente contra um culpado (Camus, 1979, p. 270-271).

A narrativa se mostra então enquanto crítica clara realizada por Camus ao absurdo institucional da sociedade, denunciando uma justiça teatral e descomprometida com a objetividade e a clareza que apregoa na construção discursiva da chamada "verdade real" buscada no processo. Reconhecendo a obscuridade dessa verdade e dessa justiça perseguidas, 
Camus compara, por meio da paródia contida no sarcástico descaso de Mersault, o funcionamento incoerente do aparato jurídico-institucional com o não menos absurdo funcionamento do acaso existencial (Olivo; Siqueira, 2008, p. 12).

Inadmitindo uma racionalidade universal capaz de conduzir os homens a um senso moral único, Camus nos leva a refletir sobre as raízes das normas que compõem o ordenamento jurídico, constituído em um exorbitante excesso normativo, o qual resulta de uma atividade incessante de codificação da realidade, que, por ser essencialmente humana, apresenta-se consequentemente imprevisível e mutável e é, assim, sempre excedente à prévia normatização.

Logo, se a norma formaliza-se posteriormente à consubstanciação dos atos que busca conformar por meio do mecanismo da exceção ${ }^{4}$ - incluindo o que dantes se localizava no campo do imprevisível -, necessário pensar de onde vem seu fundamento primeiro de legitimidade. Matos se aproxima da questão apresentando-o como a experiência da violência, que impõe uma ordem cuja função primeira seria sustentar o sistema de dominação resultante do embate de forças, justificando-o posteriormente sob a égide de um discurso sobre uma suposta racionalidade metafísica:

O nómos não é apenas a lei, guardando em si uma significação fundante do direito da qual a contemporaneidade parece ter se esquecido ao funcionalizá-lo. Schmitt explica que o substantivo nómos deriva do verbo grego némein, apresentando três significados complementares: 1 . tomar, conquistar (mesmo sentido do verbo alemão nehmen); 2. dividir e distribuir o que foi tomado; 3. pastar, quer dizer, cultivar e explorar a posse, o conquistado. Na verdade, toda ordenação normativa depende de uma prévia violência, consistente na tomada da terra. Ordem (Ordnung) e localização (Ortung) são co-extensivos.

Fiando-se nos pitagóricos, Foucault sustenta que nómos vem de nomeús, ou seja, "pastor". O governo dos homens derivaria então da noção cristã-medieval de pastorado. Pastor é quem faz a lei e indica a direção certa ao rebanho, encenando uma experiência autoritativa que os gregos só conheciam de maneira secundária e marginal. Por isso eles a localizavam no domínio privado da casa, nunca na seara propriamente política: trata-se da

4 Aqui refere-se à exceção, no sentido discutido por Schmitt e Agamben, de um momento/espaço em que o ordenamento jurídico é suspendido para inserir em si a vida nua, a vida biológica desqualificada, despida de roupagem política, repetindo o momento fundador do Direito (Agamben, 2007, p. 16-17). 
submissão de um ser humano (o filho, a esposa, o escravo etc.) à vontade pura e simples de outro (o pai), e não a um sistema abstrato de normas e padrões sociais, seja ele democrático, aristocrático ou monárquico (Matos, 2014, p. 260).

A redução simbólica do direito à lei aparece aqui como mascaramento da reprodução sistemática de uma relação de poder temporalmente consolidada. Na intenção de assim se sustentar, garante a estabilidade e o controle social por meio de normas que buscam assegurar a previsibilidade do comportamento dos indivíduos a serem governados, baseando-se em discursos de verdades sobre categorias subjetivas como bom/mau, certo/errado, moral/imoral, noções obscuras na filosofia de Camus. Nesse contexto, o autor demonstra como uma subjetividade imprevisível como a de Mersault é uma ameaça muito maior ao sistema do que o seu ato em si mesmo.

\section{CONCLUSÃO}

A curta história de $O$ estrangeiro apresenta-se como um exemplo ímpar de conectividade entre Direito e Literatura. Frente às profundas reflexões provocadas pela narrativa de Camus, autor que alcança o sucesso em abstrair e criar estreitas ligações entre Filosofia, Direito e Literatura, no sentido de realizar críticas tão contemporâneas, percebe-se que a obra se atualiza com o decorrer dos anos exatamente devido à essencialidade e à complexidade dos temas nela abordados.

Ainda que a temática do estrangeirismo na qual Camus se encontrava imerso e as influências do contexto bélico-jurídico aparentem ser assuntos datados, a obra consegue abstrair o que essas experiências trazem consigo de atemporalidade, lançando mão dos melhores frutos que a memória histórica fornece para se pensar o presente. As singularidades que nos consolidam enquanto seres únicos, a possibilidade de transpormos este vazio que nos separa e os absurdos que a dogmática e o pensamento acrítico podem gerar, quando compartilhados por um grupo que preza por uma homogeneidade de identidades artificializadas por discursos ideológicos, são pontos que devem estar sempre em pauta nos caminhos jurídicos.

Ao demonstrar o comportamento antissocial de Mersault e nos propiciar o estranhamento sensorial que sua história provoca, Camus nos 
lembra de nós mesmos e da intrínseca incoerência que jaz na vivência do ser humano em sociedade. Revelar a incompatibilidade entre a liberdade individual na qual pretendem se embasar os sujeitos de direito e uma a ordem social jurídica que se afirma objetiva e igualmente aplicável a todos, consolidada por um ordenamento coerentemente positivado, é a forma de explicitar um paradoxo, demonstrando aquilo que o autor chamou de absurdo existencial.

Pois se, para o homem, viver de acordo com todas as regras sociais que lhe são impostas é negar sua liberdade, elemento que dá sentido à sua existência como ser autônomo, por outro lado, a vida em desacordo com essas mesmas regras sociais lhe impõe punições que podem alcançar a morte, como foi o caso de Mersault, e essa também é completa desconformidade com a vida, enquanto sua negação final. Emerge então a necessidade de se pensar o alcance das sanções e os limites da atuação institucional na sociedade, na busca pelo meio termo no qual o paradoxo se mantenha equilibrado.

É claro que a postura filosófica/literária do autor torna-se hiperbolizada ao tomar um homicídio como mote para se falar de liberdade. No entanto, uma das maiores qualidades da arte é exatamente a possibilidade de criar situações extremas, nas quais o leitor/espectador se localiza e põe-se a pensar a realidade sob uma perspectiva dificilmente alcançável no mundo real da normatividade. E eis, portanto, a maestria de Camus: tornar o jurista não apenas cúmplice do assassino, mas indignado com um sistema que o condena, o mesmo sistema no qual esse jurista pauta cegamente suas atividades cotidianas.

A partir dessas questões trazidas pelo campo imaginário do qual a Literatura se serve, desse exercício de deslocamento reflexivo que percebe e assume o paradoxo exposto em sua completude, é que o jurista deve pautar suas ponderações na prática cotidiana do estudo do Direito.

\section{REFERÊNCIAS}

AGAMBEN, Giorgio. Homo sacer: poder soberano e a vida nua. 2. ed. Belo Horizonte: Editora UFMG, 2012. 207p.

BENVENISTE, Émile. O vocabulário das instituições indo-europeias: economia, parentesco, sociedade (volume I). Campinas: Unicamp, 1995. 343p. 
BITENCOURT, Cezar Roberto. Tratado de direito penal: parte geral. 13. ed. São Paulo: Saraiva, 2008. v. 1. 782p.

BRASIL. Código penal. ed. São Paulo: Revista dos Tribunais, 2010.

CAMUS, Albert. O estrangeiro. In: CAMUS, Albert. Estado de sítio: $O$ estrangeiro. São Paulo: Abril Cultural, 1979. 298p.

CAMUS, Albert. O mito de Sísifo. Disponível em: <http://www.elibs.com. br/Albert-Camus/1925-O-Mito-de-Sisifo >. Acesso em: 10 abr. 2015. 49 p.

CAMUS, Albert. O homem revoltado. São Paulo: Record, 1996. 351p.

DERRIDA, Jacques. Questão do estrangeiro: vinda do estrangeiro. In: DURFOURMANTELLE, Anne. Anne Durfourmantelle convida Jacques Derrida para falar de «hospitalidade». São Paulo: Escuta, 2003. 135p.

MATOS, Andityas Soares de Moura Costa. Filosofia radical e utopia: inapropriabilidade, an-arquia, a-nomia. Rio de Janeiro: Viavérita, 2014. 306p.

OLIVO, Luis Carlos Cancellier; SIQUEIRA, Ada Bogliolo Piancastelli de. O direito e o absurdo: uma análise de "O estrangeiro", de Albert Camus. Revista Seqüência, Florianópolis, v. 56, p. 259-276, jun. 2008.

PLATÃO. Sofista. In: PLATÃO. Diálogos. 5. ed. São Paulo: Nova Cultural, 1991a. p. 205-330.

PLATÃO. Político. In: PLATÃO. Diálogos. 5. ed. São Paulo: Nova Cultural, 1991b. p. 331-442.

SCHMITT, Carl. O conceito do político. Petrópolis: Vozes, 1992. 151p.

Submetido: 17/01/15

Aceito: 25/04/15 